\title{
Biology and ecology of the brown dog tick, Rhipicephalus sanguineus
}

\author{
Filipe Dantas-Torres
}

\begin{abstract}
The brown dog tick (Rhipicephalus sanguineus) is the most widespread tick in the world and a well-recognized vector of many pathogens affecting dogs and occasionally humans. This tick can be found on dogs living in both urban and rural areas, being highly adapted to live within human dwellings and being active throughout the year not only in tropical and subtropical regions, but also in some temperate areas. Depending on factors such as climate and host availability, Rh. sanguineus can complete up to four generations per year. Recent studies have demonstrated that ticks exposed to high temperatures attach and feed on humans and rabbits more rapidly. This observation suggests that the risk of human parasitism by Rh. sanguineus could increase in areas experiencing warmer and/or longer summers, consequently increasing the risk of transmission of zoonotic agents (e.g., Rickettsia conorii and Rickettsia rickettsii). In the present article, some aspects of the biology and ecology of Rh. sanguineus ticks are discussed including the possible impact of current climate changes on populations of this tick around the world.
\end{abstract}

\section{Review}

Ticks (suborder Ixodida) are the most important group of vectors of pathogens within the phylum Arthropoda, being comparable only to mosquitoes (family Culicidae) $[1,2]$. They are responsible for the maintenance and transmission of many pathogens affecting domestic animals and humans, including several species of bacteria, helminths, protozoa, and viruses [3].

The brown dog tick Rhipicephalus sanguineus (Figure 1 ) is the most widespread tick in the world, even considering that many ticks currently identified as Rh. sanguineus might actually represent other closely related species (e.g., Rhipicephalus turanicus). This tick is a parasite of dogs that can occasionally parasitize other hosts, including humans. Moreover, Rh. sanguineus is a vector of many disease agents, some of them (e.g., Coxiella burnetii, Ehrlichia canis, Rickettsia conorii, and Rickettsia rickettsii) being of zoonotic concern [4].

Due to its veterinary and public health relevance, $R h$. sanguineus is one of the most studied ticks. Indeed, a number of studies on its biology and ecology have been carried out in many parts of the world. Certainly, knowledge of the natural history of this tick is seminal

Correspondence: filipe.vet@globo.com

Dipartimento di Sanità Pubblica e Zootecnia, Facoltà di Medicina Veterinaria Università degli Studi di Bari, 70010 Valenzano, Bari, Italy for a better understanding of the eco-epidemiology of tick-borne diseases, such as Mediterranean spotted fever and Rocky Mountain spotted fever. Herein, some aspects of the biology and ecology of Rh. sanguineus are discussed, including the possible impact of current climate changes on populations of this tick around the world.

\section{Biology of Rhipicephalus sanguineus Ethology}

From an ethological standpoint, $R$. sanguineus is an endophilic (adapted to indoor living), monotropic (all developmental stages feed on the same host species), and three-host (each life stage requires a new host to feed on) tick species. However, although highly endophilic, $R h$. sanguineus is also able to survive in outdoor environments, mainly if refuges (e.g., limestone walls) are available. Moreover, although monotropic, this tick can occasionally feed on other hosts (e.g., humans), which do not belong to its 'natural trophic chain'. These facts indicate that $R h$. sanguineus is a catholic tick, being able to adopt different strategies for survival, as needed.

When seeking a host, the brown dog tick is a hunter (host-seeking behaviour), although it can also adopt the ambush strategy (questing behaviour). Indeed, all these 

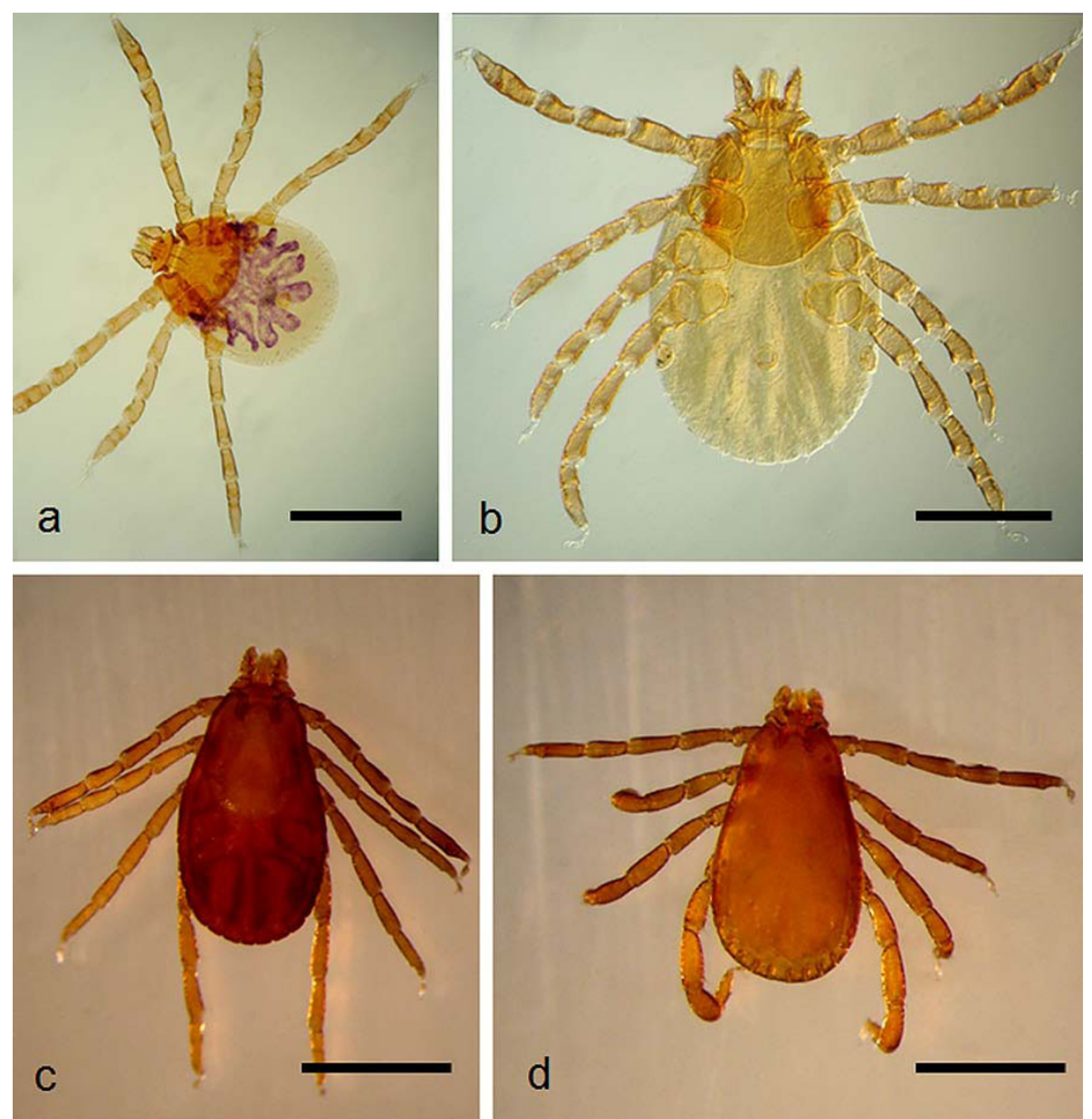

Figure 1 Immature and adult stages of Rhipicephalus sanguineus. A: larva (mounted in Hoyer's medium; bar $=400 \mu \mathrm{m}$ ). B: nymph (mounted in Hoyer's medium; bar $=0.5 \mathrm{~mm})$. C: female (bar $=1 \mathrm{~mm})$. D: male $(\mathrm{bar}=1 \mathrm{~mm})$.

behavioural patterns exhibited by $R h$. sanguineus have been acquired throughout its evolutionary history. Perhaps, these traits of this tick have evolved from its relationship with the domestic dog and their shared environment, being part the tick's strategy for survival and perpetuation.

\section{Attachment, feeding and mating}

Once on the dog, Rh. sanguineus uses its chelicerae to pierce the host's skin and then inserts its hypostome and chelicerae into the host's epidermis, occasionally reaching the upper layers of dermis [5]. During attachment, the tick secretes a cement-like substance, which forms a cone on the surface of epidermis that extends up to the stratum corneum [5]. While probing for blood, capillary and small blood vessels are lacerated and haemorrhage occurs, creating a feeding pool [6], from which the tick sucks blood and other fluids (telmophagy).

The feeding period of Rh. sanguineus can vary from two days (e.g., larvae) to several weeks (e.g., females), depending on tick developmental stage (e.g., feeding period of nymphs is longer than that of larvae) and host (e.g., engorgement of females may take longer on rabbits than on dogs) $[7,8]$. Male ticks can take multiple blood meals. Indeed, it has been shown that male ticks previously attached to one dog can move onto another cohoused dog and feed on it [9]. Furthermore, male ticks can remain for long periods of time on the host. Interestingly, it has been observed that the presence of males can increase the feeding performance of $R h$. sanguineus immature ticks, particularly nymphs [10]. This fact suggests that males may have other biological roles in addition to reproduction.

Rhipicephalus sanguineus ticks can attach everywhere on the dog, but the head (particularly on ears), interdigital spaces, back, inguinal region, and axilla (Figure 2) are among their preferred attachment sites [11-16]. Although Rhipicephalus ticks have short hypostome (Figure 3 ) and attach more superficially in comparison with others ticks (e.g., most species of Amblyomma 

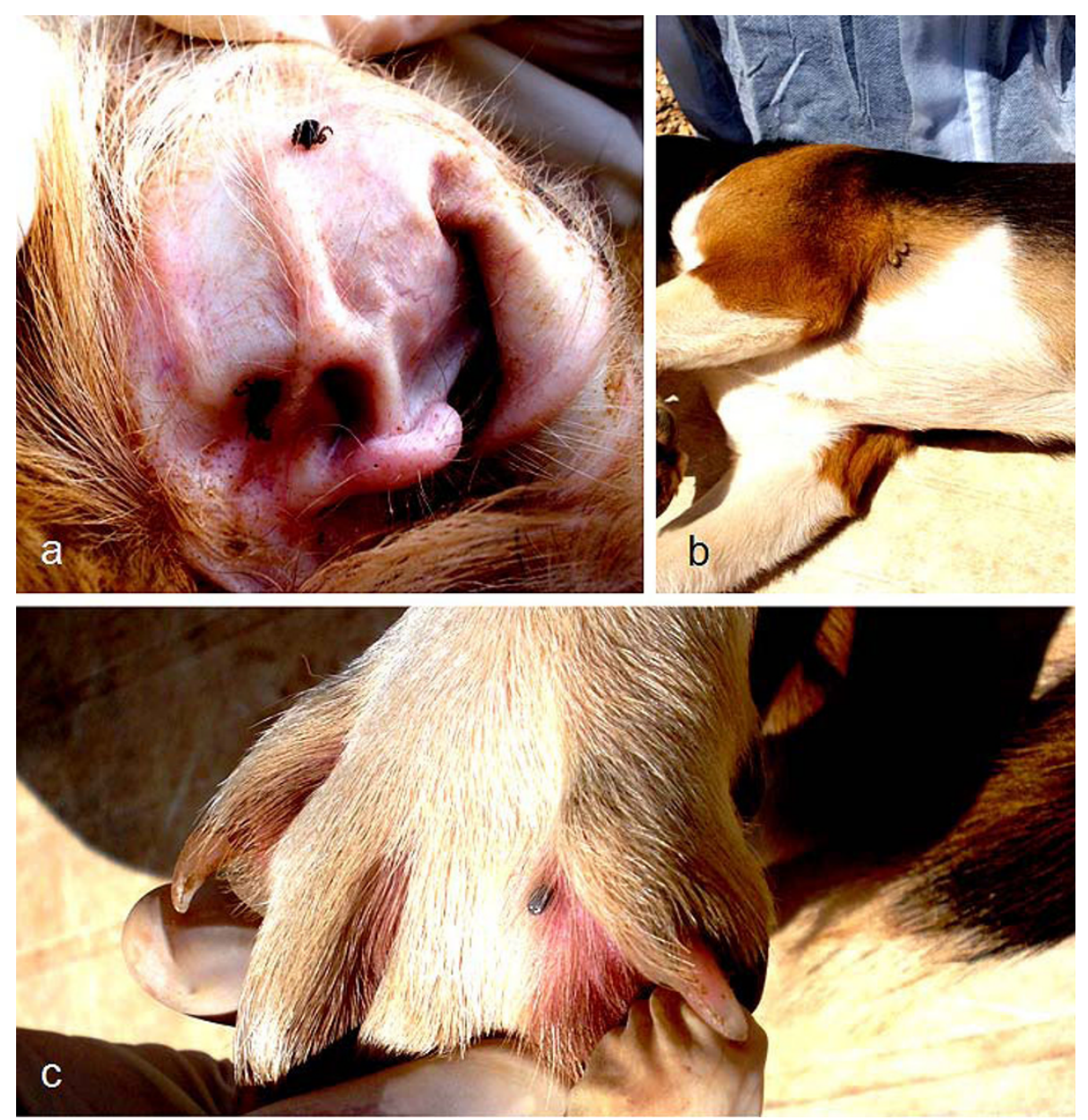

Figure 2 Attachment sites of Rhipicephalus sanguineus. A: three adults on the ear of a dog. B: two females attached to the axilla of a dog. C: an engorged nymph on the interdigital region of a dog.
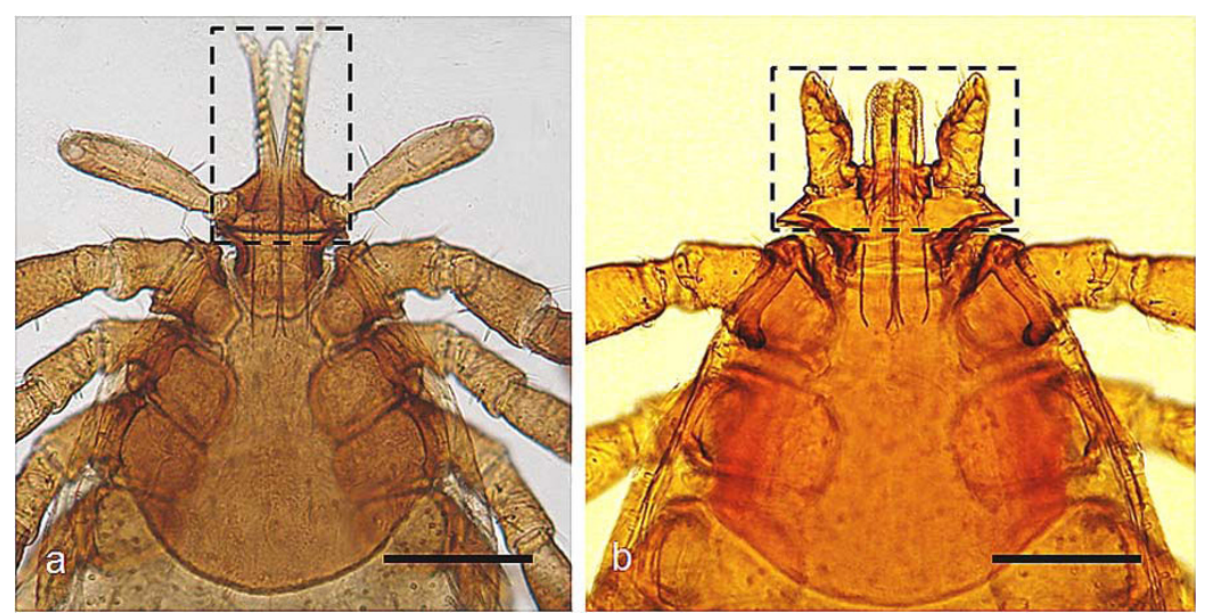

Figure 3 Tick mouthparts. A: Ixodes ricinus nymph $(\mathrm{bar}=200 \mu \mathrm{m})$. B: Rhipicephalus sanguineus nymph $(\mathrm{bar}=250 \mu \mathrm{m})$. Note the rostrum of $R \mathrm{~h}$. sanguineus (wider than long) in comparison with the one of I. ricinus (twice longer than wide). 

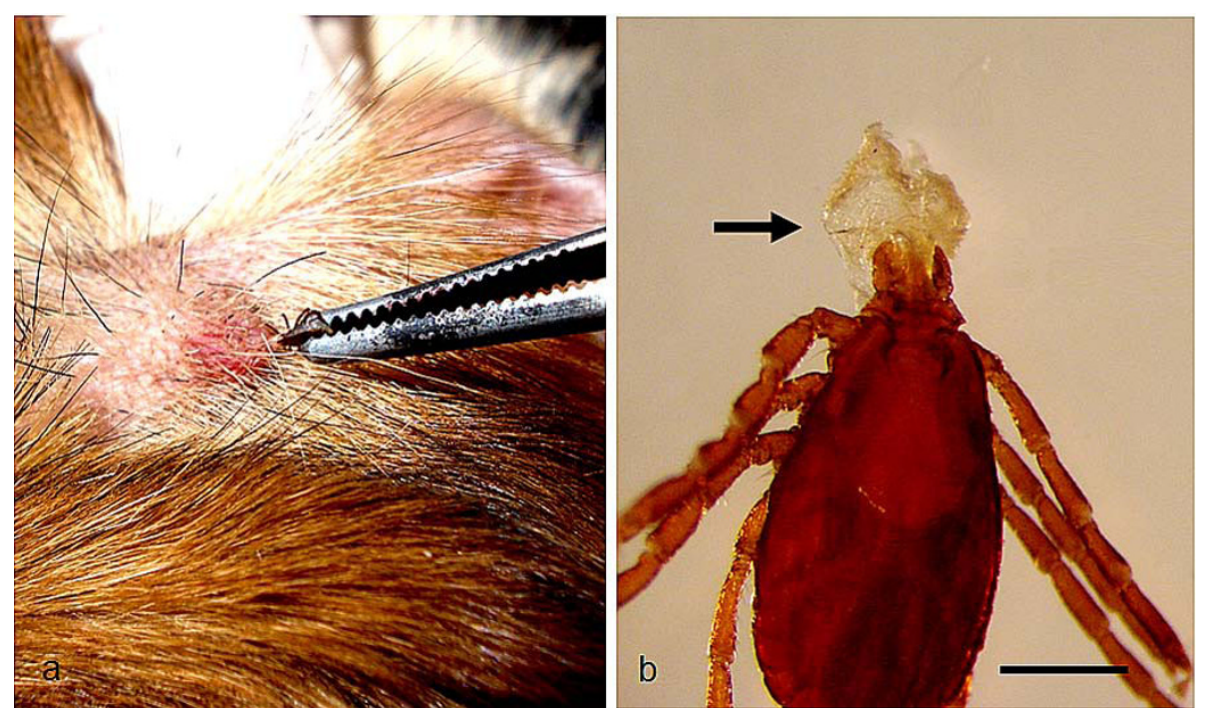

Figure 4 Attachment of Rhipicephalus sanguineus. A: A male firmly attached to the dog's skin. Note that while the tick is being gently pulled with the help of a tweezers, the skin is stretched out. B: A female exhibiting a piece of a dog's skin that remained attached to her mouthparts after her forced removal.

and Ixodes), they can attach firmly to the host's skin (Figure 4).

As a metastriate tick (lineage Metastriata), Rh. sanguineus attains sexual maturity and mates solely on the host. Although the female can start to feed even in the absence of a male, she will not become fully engorged unless mated. Indeed, the ingestion of blood is a major stimulus for spermatogenesis in males and for oogenesis in females. During mating, the male climbs onto the dorsum of the female and crawls to her ventral surface, standing in juxtaposition (venter to venter) with her. Then, the male stimulates the female genital aperture (gonopore), by inserting the tips of his chelicerae into it. Soon afterwards, the male transfers the spermatophore (a double-walled, sperm-filled sac) to the female genital aperture (Figure 5) with the help of his mouthparts [17]. The spermatophore then everts itself into the female's genital tract. Around $24 \mathrm{~h}$ after copulation, a capsule full of mature spermatozoa (spermiophores) can be found in the receptaculum seminis of dissected females [17].

\section{Drop-off rhythm}

Most ticks have a definite circadian rhythm of detachment from the host (drop-off), which is usually coordinated with host's activity [18]. Rhipicephalus sanguineus larvae exhibit a diurnal drop-off pattern [19-21], detaching mostly during the daytime. Conversely, engorged nymphs and females detach predominantly during the night period [19-21]. The reasons for this particular drop-off behaviour of larvae, nymphs, and females of $R h$. sanguineus are not fully understood, but might be related to the activities of the host as well as it might represent strategies adopted by the tick during different phases of its life cycle. In any case, this data should be taken into account while planning control measures focused on the environment, as the places where dogs stay at night are more likely to harbour the largest number of non-parasitic stages of Rh. sanguineus [21].

\section{Female oviposition and egg hatching}

When feeding is complete, the engorged female detaches from the host, drops to the ground and after a pre-oviposition period (from three days to some weeks) deposits thousands of eggs (Figure 6). Typically, females of $R h$. sanguineus oviposit uninterruptedly an average of 1500-4000 eggs $[7,22]$; however, some disturbed females (e.g., removed daily from the vials for separation and counting of the eggs) can interrupt the oviposition and then restart it the day after, although loses in terms of egg production efficiency are usually minor (unpublished observations). The oviposition period can last for several weeks and the number of eggs laid by each female is directly correlated with her weight and the length of the oviposition period [7]. Eggs are deposited in hidden places, such as cracks and crevices in the walls, between rocks, and sometimes, almost inside the ground. The females need to find a hidden place to protect themselves and their fore coming progeny, as they constitute an easy prey for predators, such as spiders [23], birds [24], and wasps [25].

The egg hatching is preceded by an incubation period that ranges from 6 days to some weeks [4]. Similarly to what occurs in other tick species, a longitudinal fissure 


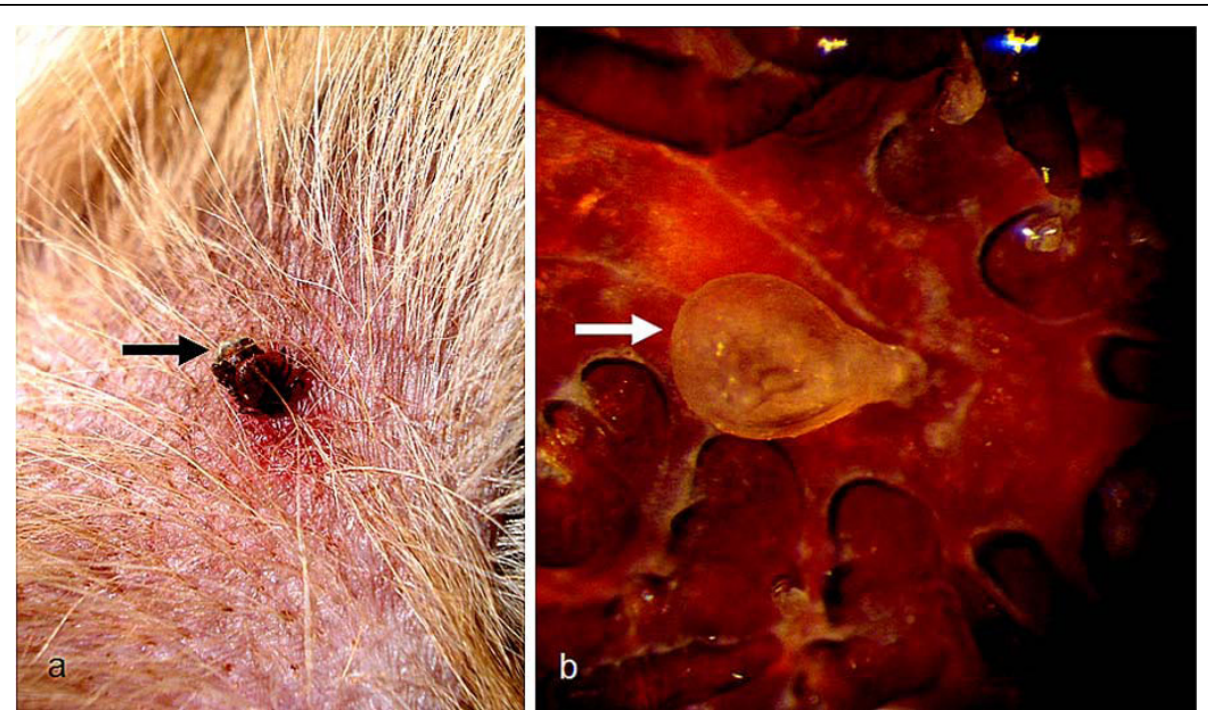

Figure 5 Mating of Rhipicephalus sanguineus. A: A couple of Rh. sanguineus mating on a dog (the male is arrowed). B: A spermatophore attached to the female genital aperture (bar $=600 \mu \mathrm{m})$.

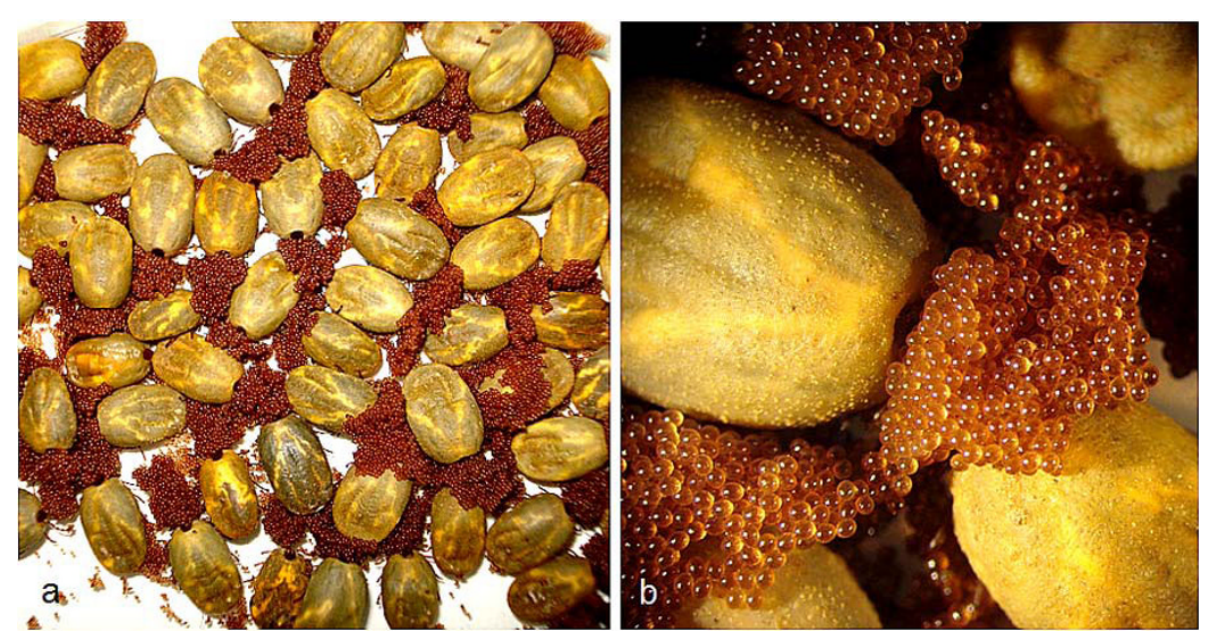

Figure 6 Oviposition of Rhipicephalus sanguineus. A: Several females laying eggs under laboratory conditions (temperature $26^{\circ} \mathrm{C}$, relative humidity, 80\%). B: A close-up of the previous image, showing in detail the newly laid eggs.

(hatching line) encircling the egg chorion can be observed at the end of the incubation period, characterizing the beginning of the hatching process, which culminates in the hatching of a flat, fragile six-legged larva. The newly hatched larva usually needs sometime to harden its chitin-made exoskeleton before seeking a host. For instance, in an experimental study, larvae younger than 7 days were unable to attach and feed on rats [22].

\section{Moulting process}

When feeding is complete, engorged larvae and nymphs detach from the host and drop to the ground to find a hidden place. The moulting process is preceded by a period of seclusion (pre-moult period) that might vary widely (from days to several weeks), depending on factors such as life stage (i.e., it takes longer in nymphs than in larvae) and weather conditions (e.g., stressful temperature and humidity can extend the moulting period). At low temperatures (e.g., at $10^{\circ} \mathrm{C}$ ), the engorged larvae and nymphs may undergo diapause and the higher is the temperature, the shorter is the moulting period [26].

As in insects, the ecydisis in ticks is regulated by moulting hormones (ecdysteroids) [27]. In Rh. sanguineus, the ecydisis starts with the rupture of the old 

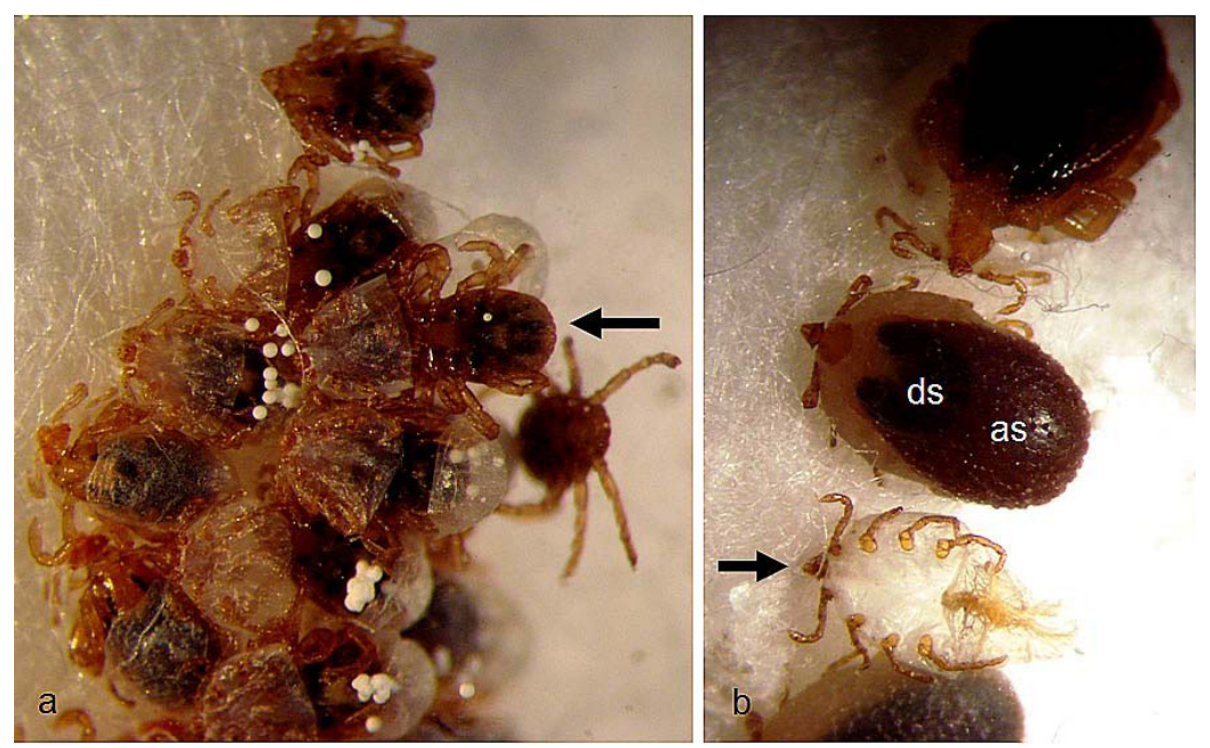

Figure 7 Moulting of Rhipicephalus sanguineus. A: A nymph (arrow) emerging from its larval exuvia. B: An engorged nymph (few hours prior the ecydisis), exhibiting the short, anterior dorsal scutum (ds) and the alloscutum (as) of a typical female. A nymphal exuvia (arrow) left behind by other female can be seen as well.

cuticula and then the old integument is moved forward by means of abdominal peristaltic waves (see additional file 1). In a few hours, the newly moulted tick emerges, leaving behind its exuvia (Figure 7).

During moulting, even prior to rupture of and emergence from its old integument, the tick starts to defecate. The faeces are initially seen as white spherules (see additional file 2) consisting of guanine, xanthine and other similar compounds [28]. These compounds result from the metabolism of the blood meal and are formed in the Malpighian tubules as the nitrogenous wastes, being accumulated in the rectal sac and eliminated via the anal pore [28]. Guanine is the most abundant component of tick excreta and is a natural semiochemical that has been identified as an assembly pheromone, inducing aggregation in many Ixodes and argasid species [28]. So far, neither guanine nor other assembly pheromones have been identified for $R h$. sanguineus ticks. What is known is that aggregation accelerates the moulting process of nymphs [29]. Interestingly, the presence of newly moulted nymphs appears to act as a mechanical stimulus for the ecdysis of other nymphs (see additional file 3) (unpublished observations).

\section{Ecology of Rhipicephalus sanguineus} On-host ecology

The domestic dog is the main host of $R h$. sanguineus in both urban and rural areas [30-32]. Occasionally, $R h$. sanguineus can infest a wide range of domestic and wild hosts, including cats, rodents, birds, and humans [33-39]. The parasitism by $R h$. sanguineus on hosts other than dogs is quite unusual in certain areas, being mainly associated to the presence of heavily infested dogs and in highly infested environments. In the same way, ticks collected from domestic and wild animals that might eventually resemble $R h$. sanguineus might actually represent other species, such as $R h$. turanicus which is often found on cattle, horses, goats, cats, and a wide range of wildlife species [36].

The likelihood of a host other than the dog being attacked by $R h$. sanguineus might vary according to tick population. For instance, the human parasitism by $R h$. sanguineus is relatively common in Europe, particularly during the summer [40]. In contrast, the human parasitism is much less common (or maybe much less reported) in South American countries [41], such as Brazil $[38,42]$.

The prevalence and mean intensity of infestation by $R h$. sanguineus on dogs can vary widely, both geographically and seasonally. These and other "on-host" ecological parameters can also vary according to diverse factors, at both population (e.g., dog population density and proportion of dogs treated with ectoparasiticides or tick repellents within a population) and individual levels (e.g., age, breed, and lifestyle). For instance, the prevalence of $R h$. sanguineus infestation on dogs can be as high as $80 \%$ in some areas, as in north-eastern Thailand [43]. The prevalence is higher among free-ranging dogs (which are usually untreated against ectoparasites) as compared with domiciled dogs [31]. Mean intensities of infestation of 3.8, 5.4, 7.8 and 39.4 have been reported in north-western Georgia (United States) [44], north-eastern Brazil [32], 
south-eastern Brazil [45], and Italy [46], respectively. In south-eastern Brazil, the prevalence and mean intensity were much higher among dogs living in houses with grassy yards as compared with dogs kept in apartments [45]. In a recent study carried out in the same region, dogs were significantly more infested during the dry season [15]. Furthermore, the tick burden is often higher among urban dogs in comparison with rural ones $[30,32,47]$. However, in some rural areas, Rh. sanguineus might be even absent and dogs can be infested by many other tick species (e.g., Amblyomma oblongoguttatum, Amblyomma ovale, and Amblyomma cajennense in eastern Amazon, Brazil) [48].

It is not rare to see some dogs infested by a single tick and others confined in the same kennel (even in the same cage) carrying hundreds of ticks. This suggests that the tick burden might also be influenced by individual dog factors, such as age and breed. Indeed, the tick burden is heavier on young dogs in comparison to older ones $[16,32]$. Young dogs heavily infested by ticks might develop anaemia, particularly if they are also infected by tick-borne pathogens, such as Ehrlichia spp. [49]. Although the prevalence of infestation is often higher among males than females [15], it is uncertain whether this is a gender-related susceptibility or a matter of exposition. Furthermore, some breeds (e.g., English cocker spaniels) are apparently more susceptible than others [50]. A more recent study has suggested that $R h$. sanguineus ticks can display distinct behavioural patterns upon exposure to odours from different dog breeds [51]. As a hunter tick, Rh. sanguineus seeks its host actively oriented by host-produced substances (kairomones), including $\mathrm{CO}_{2}$. Whether other host-produced substances can induce questing activity or even an escape-oriented behaviour in Rh. sanguineus remains uncertain.

The resistance of dogs to ticks is usually measured by comparing some biological parameters of ticks fed on tick-naïve dogs with those fed on dogs previously infested by ticks [50,52]. These biological parameters (e. g., tick yield, weight of engorged females and egg production efficiency) can provide direct or indirect evidence on the resistance of dogs to ticks. However, even though some females fed on dogs previously exposed to ticks might weigh significantly less and produce fewer eggs than those fed on tick-naive dogs, these females will still be able to produce viable offspring.

A recent study showed that $R h$. sanguineus ticks fed on resistant hosts (i.e., guinea pigs) presented several histological alterations (e.g., swelling of the epithelial cells of Malpighian tubules, an increase in guanine content secreted by Malpighian tubules, vacuolization of epithelial wall of tracheae, and vacuolization of oocytes) as compared to ticks fed on dogs [53]. However, further research employing ultrastructural and immunohistochemical techniques would be helpful to reveal the nature of these alterations.

\section{Off-host ecology}

Strange as it seems (e.g., when you see a single dog infested by hundreds of ticks), most of the ticks are not on the dog but in the environment. As a typical threehost tick, $R h$. sanguineus spends most of its lifetime in the environment, where it is under direct influence of several biotic (e.g., predators) and abiotic (e.g., weather condition) factors.

In tropical and subtropical areas, Rh. sanguineus ticks are prevalent throughout the year $[42,54,55]$ whereas in temperate regions they are most active from the late spring to early autumn [56,57]. Rhipicephalus sanguineus ticks can overwinter in the environment and even infest dogs during winter in some regions of temperate climate (e.g., south-eastern Oklahoma and north-western Arkansas, United States) [11]. However, successful oviposition, egg hatch as well as larval and nymphal moulting are unlikely at low temperature conditions $[26,58]$. In this regard, it has been shown that Rh. sanguineus can develop well under different conditions in terms of temperature (e.g., $20-35^{\circ} \mathrm{C}$ ) and relative humidity (e.g., 35-95\%) [26].

The number of generations that $R h$. sanguineus ticks can complete each year can vary from region to region. Under favourable conditions (e.g., temperature, relative humidity, and host availability), they can complete up to three or four generations per year, as recorded in centre-western Brazil $[14,15]$.

Rhipicephalus sanguineus is an endophilous tick, being usually found indoors crawling on carpets, walls, and furniture [38,59]. However, it can also be abundant in peridomestic areas, as reported in eastern Arizona $[60,61]$. They can be found walking on outside walls of houses, on the ground (between rocks), and inside cracks and crevices (Figure 8). Indeed, high levels of environmental infestation might increase the risk of human exposure to $R h$. sanguineus $[38,59,62,63]$ and thus the risk of acquiring certain tick-borne pathogens, such as $R$. rickettsii [59].

In an epidemiological study carried out in Marseille (France) it was observed that dense centres of housing were much less favourable for $R h$. sanguineus ticks than scattered ones [64]. Furthermore, it was observed that houses with gardens were more a suitable biotope for $R h$. sanguineus than the environment of large buildings [64]. Similar results have been obtained in Japan, where dogs that had contact with a garden (two weeks prior to examination) had a higher chance of being infested by Rh. sanguineus [65]. Furthermore, in the same Japanese study, this tick was most frequently associated with dogs from urban and suburban areas [65]. 

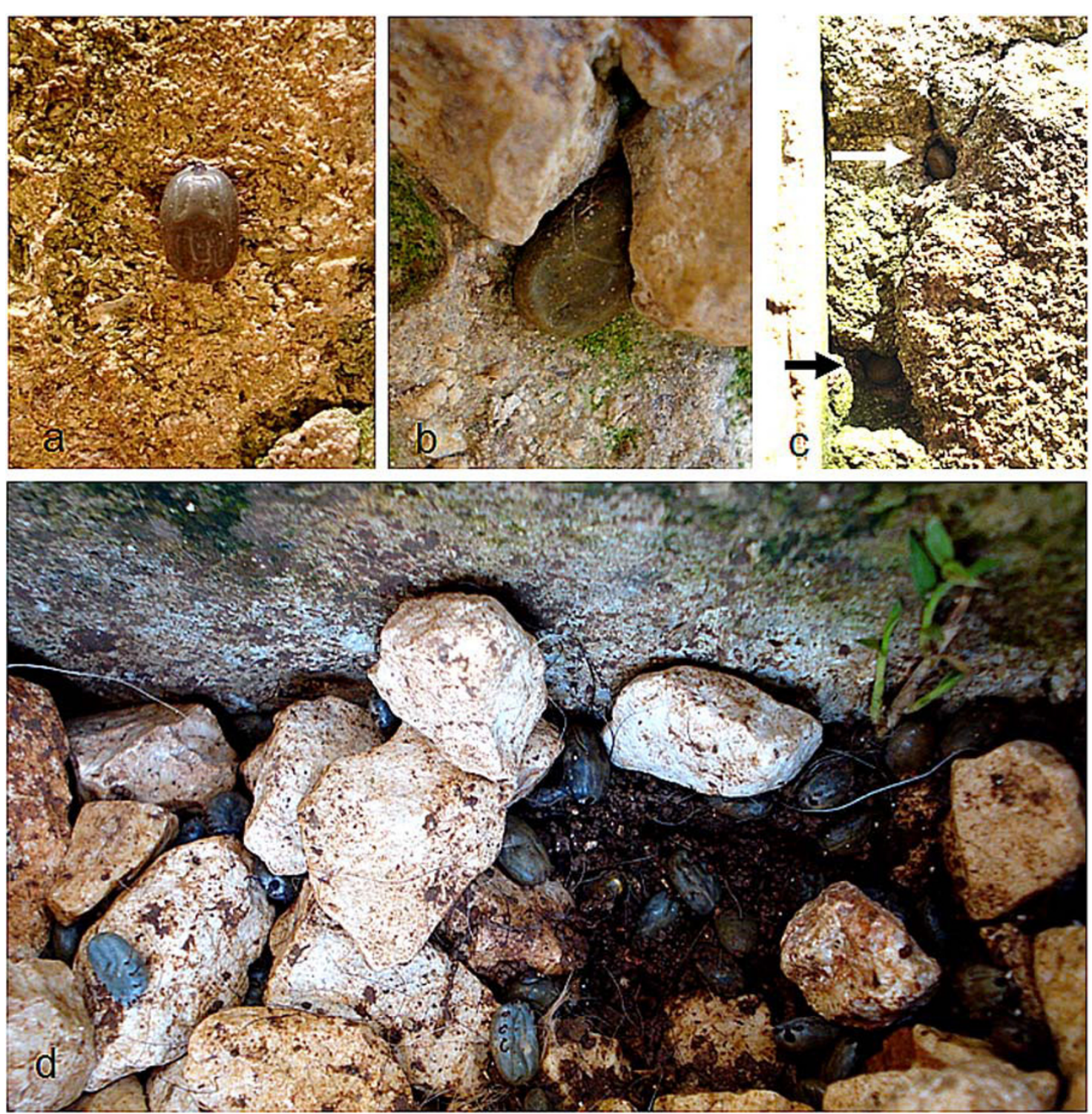

Figure 8 Hiding-places of Rhipicephalus sanguineus. A: A fully engorged female walking on a limestone wall. B and C: Engorged females (arrows) hidden in cracks of the same wall. D: Several engorged females on the ground between rocks.

Overall, studies on the ecology of $R h$. sanguineus show that this tick is well-adapted to live within human dwellings, being also capable to colonize peridomiciliary environments (e.g., gardens and kennels) if the weather is suitable and if hosts are available.

\section{The brown dog tick, global warming, human parasitism, and tick-borne diseases}

The brown dog tick is an ectoparasite of public health significance, being involved in the transmission of major human pathogens, as it is the case of $R$. rickettsii [66]. There has been a lot of discussion about climate changes and their impact on ticks and on the eco-epidemiology of tick-borne diseases [67]. Tick biology and ecology are under the direct influence of climate factors, such as temperature and humidity. Indeed, while global warming might affect the survival of some tick species that are adapted to live in humid environments (e.g., Atlantic rainforest), it will probably have only a minor (if any) negative impact on ticks like $R h$. sanguineus that are less dependent upon a moisture-rich habitat for survival [68] and more resistant to desiccating conditions [26]. On the contrary, the global warming might prompt the establishment of tick populations in previously free areas. For instance, it has been speculated that an increase of about $2-3^{\circ} \mathrm{C}$ in the mean temperature from April to September could result in the establishment of populations of Rh. sanguineus in regions of northern 
temperate Europe [67]. However, the actual impact of global warming on Rh. sanguineus ticks is uncertain.

Interestingly, recent studies have demonstrated that $R h$. sanguineus ticks exposed to high temperatures attach more rapidly to rabbits and humans $[40,69]$. Therefore, it has been suggested that the risk of human parasitism could increase in areas that are experiencing warmer and/or longer summers, which could ultimately increase the risk of transmission of some pathogens, such as $R$. conorii [40]. It is important to stress that exposure to light and high temperature provoke excitation and induce increased questing behaviour not only in Rh. sanguineus, but in any tick species, particularly in those parasitic on homeothermic vertebrates.

Cases of human parasitism by Rh. sanguineus ticks have sporadically been described in the literature $[38,59,62,70-76]$ and the risk factors associated to this parasitism include dog ownership, presence of infested dogs indoors and high level of environmental infestation. In Brazil, people dealing daily with dogs (e.g., veterinarians, pet shop workers, and dog owners) appear to be at risk of exposure to Rh. sanguineus $[38,42]$. In south-east Nigeria, in an outbreak of human parasitism by $R h$. sanguineus, the grounds of the family dwelling, the sheep pens, and dog kennels were heavily infested by Rh. sanguineus [63]. Indeed, the higher is the level of environmental infestation, the higher is the risk of human exposure to Rh. sanguineus ticks.

\section{Concluding remarks and research needs}

Dogs can be affected by a number of vector-borne diseases $[77,78]$, most of which are transmitted by ticks. Among the tick species implicated in the transmission of pathogens to them [79-81], Rh. sanguineus is undoubtedly the most important species from the veterinary standpoint. Moreover, in the era of globalization and climate changes, the brown dog tick has becoming increasingly relevant from a public health perspective. This tick has also been implicated in the transmission of pathogens of zoonotic concern (e.g., R. rickettsii) and recent studies have shown that $R h$. sanguineus ticks exposed to high temperatures are more prone to bite humans [40]. This scenario highlights that the climate warming could affect $R h$. sanguineus populations of around the world and, consequently, the epidemiology of certain tick-borne infections [40].

Another important issue to be considered is the taxonomy of the genus Rhipicephalus and, in particular, of the Rh. sanguineus group that has long been a subject of research $[82,83]$. The main problem is that the type-specimen of Rh. sanguineus has been lost [82] and, therefore, a bona fide taxonomic definition of this species is currently lacking. This taxonomic question needs to be resolved in the near future to avoid misidentifications and misleading on the role of Rhipicephalus spp. ticks in the epidemiology of tick-borne diseases.

As previously mentioned in this article, some dog breeds appear to be more resistant than others [50] to infestations by $R h$. sanguineus. Further studies on the possible role of individual dog factors (e.g., genetics and nutritional status) on the susceptibility of dogs to ticks are needed. Specifically, it would be interesting to investigate whether previous tick infestations could reduce the number of successive tick bites and thus the risk of infection by tick-borne pathogens, for example, E. canis and Babesia vogeli.

Although dogs are the main hosts of Rh. sanguineus, the finding of this tick on wild canids [37] indicates that free-ranging wild canids might be involved in its maintenance and dispersion through different regions. This could have implications in the control of ticks and in the epidemiology of tick-borne diseases, particularly in areas where dogs live in close contact with their wild counterparts.

In conclusion, all topics stressed above are worthy of research in the future. Data from these studies would provide new insights into the biology and ecology of $R h$. sanguineus and ultimately prompt the development of optimized strategies for the control of this tick and the pathogens it transmits.

Additional file 1: Ecdysis. This video shows a female during the ecdysis process. Note the contractions of the idiosome, which is driven by regular peristaltic waves, and the exuvia that is being slipped off backwards.

Additional file 2: Moulting of nymphs. This video display several nymphs during the moulting process. Note a newly moulted nymph literally entering into the exuvia of another nymph, somehow stimulating its emergence.

Additional file 3: Excretion. This video shows the exact moment of the excretion of a white spherule (faeces) by a female prior to its emergence of the nymphal exuvia.

\section{Acknowledgements}

I would like to express my thanks to Luciana A. Figueredo and Professor Domenico Otranto for their invaluable suggestions on a draft of this manuscript. Thanks also to Dr. Riccardo Lia and Viviana Domenica Tarallo for their assistance in taking some of the pictures of ticks on dogs presented in this article. Publication of the thematic series has been sponsored by Bayer Animal Health $\mathrm{GmbH}$.

\section{Competing interests}

The author declares that they have no competing interests.

Received: 28 January 2010 Accepted: 8 April 2010

Published: 8 April 2010

\section{References}

1. Hoogstraal H: Argasid and nuttalliellid ticks as parasites and vectors. Adv Parasitol 1985, 24:135-238.

2. Marcondes CB: Doenças transmitidas e causadas por artrópodes. São Paulo: Editora Atheneu 2009. 
3. Jongejan F, Uilenberg G: The global importance of ticks. Parasitology 2004 129(Suppl 1):S3-S14.

4. Dantas-Torres F: The brown dog tick, Rhipicephalus sanguineus (Latreille, 1806) (Acari: Ixodidae): from taxonomy to control. Vet Parasitol 2008, 152:173-185.

5. Szabó MP, Bechara GH: Sequential histopathology at the Rhipicephalus sanguineus tick feeding site on dogs and guinea pigs. Exp Appl Acarol 1999, 23:915-928.

6. Mans BJ, Neitz AW: Adaptation of ticks to a blood-feeding environment: evolution from a functional perspective. Insect Biochem Mol Biol 2004, 34:1-17.

7. Koch HG: Oviposition of the brown dog tick (Acari: Ixodidae) in the laboratory. Ann Entomol Soc Am 1982, 75:583-586.

8. Troughton DR, Levin ML: Life cycles of seven ixodid tick species (Acari: Ixodidae) under standardized laboratory conditions.J Med Entomol 2007, 44:732-740.

9. Little SE, Hostetler J, Kocan KM: Movement of Rhipicephalus sanguineus adults between co-housed dogs during active feeding. Vet Parasitol 2007, 150:139-145

10. Rechav $Y$, Nuttall PA: The effect of male ticks on the feeding performance of immature stages of Rhipicephalus sanguineus and Amblyomma americanum (Acari: Ixodidae). Exp Appl Acarol 2000, 24:569-578.

11. Koch HG: Seasonal incidence and attachment sites of ticks (Acari: Ixodidae) on domestic dogs in southeastern Oklahoma and northwestern Arkansas, USA. J Med Entomol 1982, 19:293-298.

12. Mumcuoglu KY, Frish K, Sarov B, Manor E, Gross E, Gat Z, Galun R: Ecological studies on the brown dog tick Rhipicephalus sanguineus (Acari: Ixodidae) in southern Israel and its relationship to spotted fever group rickettsiae. J Med Entomol 1993, 30:114-121.

13. Papazahariadou MG, Saridomichelakis MN, Koutinas AF, Papadopoulos EG, Leontides L: Tick infestation of dogs in Thessaloniki, northern Greece. Med Vet Entomol 2003, 17:110-113.

14. Louly CCB, Fonseca IN, Oliveira VF, Linhares GFC, Menezes LB, Borges LMF: Seasonal dynamics of Rhipicephalus sanguineus (Acari: Ixodidae) in dogs from a police unit in Goiania, Goias, Brazil. Cienc Rural 2007, 37:464-469.

15. Silveira JA, Passos LM, Ribeiro MF: Population dynamics of Rhipicephalus sanguineus (Latrielle, 1806) in Belo Horizonte, Minas Gerais state, Brazil. Vet Parasitol 2009, 161:270-275.

16. Tinoco-Gracia L, Quiroz-Romero H, Quintero-Martínez MT, RenteríaEvangelista TB, González-Medina Y, Barreras-Serrano A, Hori-Oshima S, Moro MH, Vinasco J: Prevalence of Rhipicephalus sanguineus ticks on dogs in a region on the Mexico-USA border. Vet Rec 2009, 164:59-61.

17. Feldman-Muhsam B, Borut S: Copulation in ixodid ticks. J Parasitol 1971, 57:630-634.

18. Oliver JH Jr: Biology and systematics of ticks (Acari: Ixodida). Annu Rev Ecol Syst 1989, 20:397-430.

19. Hadani A, Rechav Y: Tick-host relationships. 1. The existence of a circadian rhythm of "drop-off" of engorged ticks from their hosts. Acta Trop 1969, 26:173-179.

20. Jacobs PA, Fourie L, Horak IG: A laboratory comparison of the life cycles of the dog ticks Haemaphysalis leachi and Rhipicephalus sanguineus. Onderstepoort J Vet Res 2004, 71:15-28.

21. Paz GF, Labruna MB, Leite RC: Ritmo de queda de Rhipicephalus sanguineus (Acari: Ixodidae) de cães artificialmente infestados. Rev Bras Parasitol Vet 2008, 17:139-144.

22. Srivastava SC, Varma MGR: The culture of the tick Rhipicephalus sanguineus (Latreille) (Ixodidae) in the laboratory. J Med Entomol 1964, 1:154-157.

23. Sautet J: Invasion domiciliare de Rhipicephalus sanguineus et de Teutana triangulosa. Role ixodiphage dês araignees. Ann Parasitol Hum Comp 1936, 14:126-129.

24. Guglielmone AA, Mosa SG: Predation of ticks of the Rhipicephalus sanguineus (Latreille, 1806) group and Boophilus microplus (Canestrini, 1888) (Acari: Ixodidae) by Nothura Temminck, 1815 (Aves: Tinamidae) in Salta, Argentina. Folia Parasitol (Praha) 1991, 38:114.

25. Coronado A: Ixodiphagus hookeri Howard, 1907 (Hymenoptera: Encyrtidae) in the brown dog tick Rhipicephalus sanguineus Latreille, 1806 (Acari: Ixodidae) in Venezuela. Entomotropica 2006, 21:61-64.
26. Koch HG, Tuck MD: Molting and survival of the brown dog tick (Acari: Ixodidae) under different temperatures and humidities. Ann Entomol Soc Am 1986, 79:11-14.

27. Rees HH: Hormonal control of tick development and reproduction. Parasitology 2004, 129(Suppl 1):S127-143.

28. Sonenshine DE: Tick pheromones and their use in tick control. Annu Rev Entomol 2006, 51:557-580.

29. Cançado PH, Piranda EM, Faccini JL: Influência docomportamento gregário nos processos de muda de Rhipicephalus sanguineus (Latreille, 1806) (Acari: Ixodidae), em condições laboratoriais. Rev Bras Parasitol Vet 2007, 16:205-210.

30. Szabó MP, Cunha TM, Pinter A, Vicentini F: Ticks (Acari: Ixodidae) associated with domestic dogs in Franca region, São Paulo, Brazil. Exp Appl Acarol 2001, 25:909-916.

31. Dantas-Torres F, Figueredo LA, Faustino MAG: Ectoparasitos de cães provenientes de alguns municípios da Região Metropolitana do Recife, Pernambuco, Brasil. Rev Bras Parasitol Vet 2004, 13:151-154.

32. Dantas-Torres F, Melo MF, Figueredo LA, Brandão-Filho SP: Ectoparasite infestation on rural dogs in the municipality of São Vicente Férrer, Pernambuco, Northeastern Brazil. Rev Bras Parasitol Vet 2009, 18:75-77.

33. Saxena VK, Maheshwari UK: Seasonal incidence of Rhipicephalus sanguineus (Lat) (Acarina) on a wild host Hemiechinus auritus collaris Gray) (Insectivora). J Commun Dis 1985, 17:227-229.

34. Iori A, Lanfranchi P, Manilla G: Contribution to the knowledge of Ixodidae ticks of wild mammals of Somalia. Parassitologia 1996, 38:571-573.

35. Estrada-Peña A, Jongejan F: Ticks feeding on humans: a review of records on human-biting Ixodoidea with special reference to pathogen transmission. Exp Appl Acarol 1999, 23:685-715.

36. Walker JB, Keirans JE, Horak IG: Genus Rhipicephalus (Acari, Ixodidae). A guide to the brown ticks of the world. Cambridge: Cambridge University Press 2000.

37. Labruna MB, Jorge RS, Sana DA, Jácomo AT, Kashivakura CK, Furtado MM, Ferro C, Perez SA, Silveira L, Santos TS Jr, Marques SR, Morato RG, Nava A, Adania CH, Teixeira RH, Gomes AA, Conforti VA, Azevedo FC, Prada CS, Silva JC, Batista AF, Marvulo MF, Morato RL, Alho CJ, Pinter A, Ferreira PM, Ferreira F, Barros-Battesti DM: Ticks (Acari: Ixodida) on wild carnivores in Brazil. Exp Appl Acarol 2005, 36:149-163.

38. Dantas-Torres F, Figueredo LA, Brandão-Filho SP: Rhipicephalus sanguineus (Acari: Ixodidae), the brown dog tick, parasitizing humans in Brazil. Rev Soc Bras Med Trop 2006, 39:64-67.

39. Dantas-Torres F, Ferreira DR, de Melo LM, Lima PA, Siqueira DB, Rameh-deAlbuquerque $L C$, de Melo AV, Ramos JA: Ticks on captive and free-living wild animals in northeastern Brazil. Exp Appl Acarol 2010, 50:181-189.

40. Parola P, Socolovschi C, Jeanjean L, Bitam I, Fournier PE, Sotto A, Labauge P, Raoult $\mathrm{D}$ : Warmer weather linked to tick attack and emergence of severe rickettsioses. PLoS Negl Trop Dis 2008, 2:e338.

41. Guglielmone AA, Beati L, Barros-Battesti DM, Labruna MB, Nava S, Venzal JM, Mangold AJ, Szabó MP, Martins JR, González-Acuña D, EstradaPeña A: Ticks (Ixodidae) on humans in South America. Exp Appl Acarol 2006, 40:83-100.

42. Louly CCB, Fonseca IN, Oliveira VF, Borges LMF: Ocorrência de Rhipicephalus sanguineus em trabalhadores de clínicas veterinárias e canis, no município de Goiânia, GO. Cienc Anim Bras 2006, 7:103-106.

43. Nithikathkul C, Polseela R, lamsa-ard J, Wongsawad C, Jittapalapong S: A study of ectoparasites of Canis lupus familiaris in Mueang district, Khon Kaen, Thailand. Southeast Asian J Trop Med Public Health 2005, 36(Suppl 4):149-151

44. Goldberg M, Recha Y, Durden LA: Ticks parasitizing dogs in northwestern Georgia. J Med Entomol 2002, 39:112-114.

45. Soares AO, Souza AD, Feliciano EA, Rodrigues AF, D'Agosto M, Daemon E: Avaliação ectoparasitológica e hemoparasitológica em cães criados em apartamentos e casas com quintal na cidade de Juiz de Fora, MG. Rev Bras Parasitol Vet 2006, 15:13-16.

46. Otranto D, Lia RP, Cantacessi C, Galli G, Paradies P, Mallia E, Capelli G: Efficacy of a combination of imidacloprid $10 \%$ /permethrin $50 \%$ versus fipronil $10 \% /(S)$-methoprene $12 \%$, against ticks in naturally infected dogs. Vet Parasitol 2005, 130:293-304.

47. Neves L, Afonso S, Horak IG: Ixodid ticks on dogs in southern Mozambique. Onderstepoort J Vet Res 2004, 71:279-83. 
48. Labruna MB, Homem VS, Heinemann MB, Ferreira Neto JS: Ticks (Acari: Ixodidae) associated with rural dogs in Uruará, eastern Amazon, Brazil. J Med Entomol 2000, 37:774-776.

49. Kordick SK, Breitschwerdt EB, Hegarty BC, Southwick KL, Colitz CM, Hancock SI, Bradley JM, Rumbough R, Mcpherson JT, MacCormack JN: Coinfection with multiple tick-borne pathogens in a Walker Hound kennel in North Carolina. J Clin Microbiol 1999, 37:2631-2638.

50. Louly CCB, Soares S, Silveira D, Neto O, Silva A, Borges L: Differences in the susceptibility of two breeds of dogs, English cocker spaniel and beagle, to Rhipicephalus sanguineus (Acari: Ixodidae). Inter J Acarol 2009, 35:25-32.

51. Louly CC, Soares SF, da Nóbrega Silveira D, Guimarães MS, Borges LM: Differences in the behavior of Rhipicephalus sanguineus tested against resistant and susceptible dogs. Exp Appl Acarol

52. Inokuma H, Tamura K, Onishi T: Dogs develop resistance to Rhipicephalus sanguineus. Vet Parasitol 1997, 69:295-297.

53. Veronez VA, de Castro MB, Bechara GH, Szabó MP: Histopathology of Rhipicephalus sanguineus (Acari: Ixodidae) ticks fed on resistant hosts. Exp Appl Acarol 2010, 50:151-161.

54. Goddard J: Ticks of medical importance occurring in the Western Hemisphere. Texas: USAF School of Aerospace Medicine 1987.

55. Jacobs PAH, Fourie LJ, Kok DJ, Horak IG: Diversity, seasonality and sites of attachment of adult ixodid ticks on dogs in the central region of the Free State Province, South Africa. Onderstepoort J Vet Res 2001, 68:281-290.

56. Gilot B: Biologie et ecologie de Rhipicephalus sanguineus (Latreille, 1806) (Acariens, Ixodoidea) dans le Sud-Est de la France. Bull Soc Sci Vet Med Comp 1984, 86:25-33.

57. Papadopoulos B, Morel PC, Aeschlimann A: Ticks of domestic animals in the Macedonia region of Greece. Vet Parasitol 1996, 63:25-40.

58. Inokuma H, Tamura K, Onishi T: Seasonal occurrence of Rhipicephalus sanguineus in Okayama Prefecture, Japan and effect of temperature on development of the tick. J Vet Med Sci 1996, 58:225-228.

59. Demma LJ, Traeger MS, Nicholson WL, Paddock CD, Blau DM, Eremeeva ME, Dasch GA, Levin ML, Singleton J Jr, Zaki SR, Cheek JE, Swerdlow DL, McQuiston JH: Rocky Mountain spotted fever from an unexpected tick vector in Arizona. N Engl J Med 2005, 353:587-594.

60. Demma LJ, Eremeeva M, Nicholson WL, Traeger M, Blau D, Paddock C, Levin M, Dasch G, Cheek J, Swerdlow D, McQuiston J: An outbreak of Rocky Mountain Spotted Fever associated with a novel tick vector, Rhipicephalus sanguineus, in Arizona, 2004: preliminary report. Ann N Y Acad Sci 2006, 1078:342-343.

61. Nicholson WL, Paddock CD, Demma L, Traeger M, Johnson B, Dickson J, McQuiston J, Swerdlow D: Rocky Mountain spotted fever in Arizona: documentation of heavy environmental infestations of Rhipicephalus sanguineus at an endemic site. Ann N Y Acad Sci 2006, 1078:338-341.

62. Uspensky I, loffe-Uspensky I: The dog factor in brown dog tick Rhipicephalus sanguineus (Acari: Ixodidae) infestations in and near human dwellings. Int J Med Microbiol 2002, 291:156-163.

63. Okoli IC, Okoli CG, Opara M: Environmental and multi-host infestation of the brown dog tick, Rhipicephalus sanguineus in Owerri, south-east Nigeria - a case report. Vet Arhiv 2006, 76:93-100.

64. Gilot B, Laforge ML, Cabassu JP, Romani M: Éléments pourla cartographie écologique des populations de Rhipicephalus du groupe sanguineus (Acariens, Ixodoidea) dans l'agglomération Marseillaise, en relation avec les diverses formes d'urbanisation. Acarologia 1992, 33:17-33.

65. Shimada Y, Beppu T, Inokuma H, Okuda M, Onishi T: Ixodid tick species recovered from domestic dogs in Japan. Med Vet Entomol 2003, 17:38-45.

66. Dantas-Torres F: Rocky Mountain spotted fever. Lancet Infect Dis 2007, 7:724-732.

67. Gray JS, Dautel H, Estrada-Peña A, Kahl O, Lindgren E: Effects of climate change on ticks and tick-borne diseases in Europe. Interdiscip Perspect Infect Dis 2009, 2009:593232.

68. Yoder JA, Benoit JB, Rellinger EJ, Tank JL: Developmental profiles in tick water balance with a focus on the new Rocky Mountain spotted fever vector, Rhipicephalus sanguineus. Med Vet Entomol 2006, 20:365-372.

69. Socolovschi C, Raoult D, Parola P: Influence of temperature on the attachment of Rhipicephalus sanguineus ticks on rabbits. Clin Microbiol Infect 2009, 15:326-327.

70. Goddard J: Focus of human parasitism by the brown dog tick, Rhipicephalus sanguineus (Acari: Ixodidae). J Med Entomol 1989, 26:628-629.
71. Carpenter TL, McMeans MC, McHugh CP: Additional instances of human parasitism by the brown dog tick (Acari: Ixodidae). J Med Entomol 1990, 27:1065-1066.

72. Gilot B, Laforge ML, Pichot J, Raoult D: Relationships between the Rhipicephalus sanguineus complex ecology and Mediterranean spotted fever epidemiology in France. Eur J Epidemiol 1990, 6:357-362.

73. Felz MW, Durden LA, Oliver JH Jr: Ticks parasitizing humans in Georgia and South Carolina. J Parasitol 1996, 82:505-508.

74. Harrison BA, Engber BR, Apperson CS: Ticks (Acari: Ixodida) uncommonly found biting humans in North Carolina. J Vector Ecol 1997, 22:6-12.

75. Manfredi MT, Dini V, Piacenza S, Genchi C: Tick species parasitizing people in an area endemic for tick-borne diseases in north-western Italy. Parassitologia 1999, 41:555-560.

76. Fernández-Soto P, Pérez-Sánchez R, Alamo-Sanz R, Encinas-Grandes A: Spotted fever group rickettsiae in ticks feeding on humans in northwestern Spain: is Rickettsia conorii vanishing? Ann N Y Acad Sci 2006, 1078:331-333.

77. Dantas-Torres F: Canine vector-borne diseases in Brazil. Parasit Vectors 2008, 1:25

78. Otranto D, Dantas-Torres F, Breitschwerdt EB: Managing canine vectorborne diseases of zoonotic concern: part one. Trends Parasitol 2009, 25:157-163.

79. Regendanz P, Muniz J: O Rhipicephalus sanguineus como transmissor da piroplasmose canina no Brasil. Mem Inst Oswaldo Cruz 1936, 31:81-84.

80. Ewing SA, Mathew JS, Panciera RJ: Transmission of Hepatozoon americanum (Apicomplexa: Adeleorina) by ixodids (Acari: Ixodidae). $J$ Med Entomol 2002, 39:631-634.

81. Forlano M, Scofield A, Elisei C, Fernandes KR, Ewing SA, Massard CL: Diagnosis of Hepatozoon spp. in Amblyomma ovale and its experimental transmission in domestic dogs in Brazil. Vet Parasitol 2005, 134:1-7.

82. Pegram RG, Keirans JE, Clifford CM, Walker JB: Clarification of the Rhipicephalus sanguineus group (Acari, Ixodoidea, Ixodidae). II. $R$. sanguineus (Latreille, 1806) and related species. Syst Parasitol 1987, 10:27-44.

83. Burlini L, Teixeira KR, Szabó MP, Famadas KM: Molecular dissimilarities of Rhipicephalus sanguineus (Acari: Ixodidae) in Brazil and its relation with samples throughout the world: is there a geographical pattern? Exp Appl Acarol.

doi:10.1186/1756-3305-3-26

Cite this article as: Dantas-Torres: Biology and ecology of the brown dog tick, Rhipicephalus sanguineus. Parasites \& Vectors 2010 3:26.

\section{Submit your next manuscript to BioMed Central and take full advantage of:}

- Convenient online submission

- Thorough peer review

- No space constraints or color figure charges

- Immediate publication on acceptance

- Inclusion in PubMed, CAS, Scopus and Google Scholar

- Research which is freely available for redistribution

Submit your manuscript at www.biomedcentral.com/submit
Biomed Central 